\title{
PENYUSUNAN NERACA PERUBAHAN PENGGUNAAN LAHAN DI KECAMATAN UMBULHARJO KOTA YOGYAKARTA BERBANTUAN TEKNIK PENGINDERAAN JAUH DAN SISTEM INFORMASI GEOGRAFIS
}

\author{
Oleh: \\ Melania Swetika Rini ${ }^{1}$ dan Bambang Syaeful Hadi ${ }^{2}$ \\ ${ }^{1}$ Program Studi Pendidikan Geografi FKIP Universitas Widya Dharma Klaten \\ Email:melanieajmala@gmail.com \\ 2 Jurusan Pendidikan Geografi FIS Universitas Negeri Yogyakarta \\ Email: bb.saefulhadi@yahoo.com
}

\begin{abstract}
Abstrak
Penelitian ini bertujuan untuk: (1) mengetahui tingkat ketelitian hasil interpretasi foto udara pankromatik hitam putih skala 1:8900 tahun 1996 dan citra Quickbird berwarna skala 1:5400 tahun 2008 untuk interpretasi penggunaan lahan; (2) menyusun neraca penggunaan lahan yang mengacu kepada pedoman baku jarak penggunaan lahan; (3) menyusun neraca penggunaan lahan yang mengacu kepada pedoman baku luas penggunaan lahan; dan (4) mengetahui perbedaan penggunaan lahan dilihat dari standar jarak dan standar luas antara penggunaan lahan tahun 1996 dan 2008 di wilayah Kecamatan Umbulharjo Kota Yogyakarta.Penelitian ini merupakan penelitian deskriptif kuantitatif dengan menggunakan teknik penginderaan jauh khususnya interpretasi foto udara dan citra Quickbird dan Sistem Informasi Geografis (SIG). Populasi penelitian berupa unit-unit penggunaan lahan di wilayah Kecamatan Umbulharjo Kota Yogyakarta. Teknik sampling untuk uji ketelitian adalah proporsional dan purposive sampling, jumlah sample ditentukan berdasar Formula Anderson. Untuk keperluan analisis statistik jumlah sampel ditentukan berdasar Nomogram Harry King dengan derajat kesalahan 6\%, teknik samplingnya adalah proportional dan simple random sampling. Teknik pengumpulan data yang digunakan adalah dokumentasi, observasi dan interpretasi citra. Teknik analisis data dalam penelitian ini adalah uji ketelitian hasil interpretasi dengan Confusion Matrix Calculation, analisis SIG (Overlay dan Single Buffer) dan Uji-t.Hasil penelitian menunjukkan bahwa: (1) hasil interpretasi foto udara pankromatik hitam putih skala 1:8900 tahun 1996 dan citra Quickbird masing-masing memiliki ketelitian 85\% dan 90,02\%; (2) Berdasarkan interpretasi foto udara, luas penggunaan lahan yang distandarisasi menurut standar luas seharusnya adalah 99.535 ha dan di lapangan terdapat 336,616 ha. Berdasarkan standar jarak, luas penggunaan lahan terluas adalah jarak terhadap taman/cagar, yakni 361,134 ha dan luas lahan yang paling sempit adalah jarak terhadap tempat bermain anak, yakni 68,908 ha; (3) Neraca penggunaan lahan ditunjukkan oleh luas lahan yang distandarisasi tahun 2008 seharusnya adalah 117,153 ha, di lapangan terdapat 282,116 ha. Berdasarkan standar jarak terhadap fasilitas umum, penggunaan lahan yang paling luas adalah jarak lahan terhadap pusat kota, SMP, dan taman/cagar, masing-masing seluas 477,861 ha; dan (4) Terdapat perbedaan yang signifikan antara penggunaan lahan tahun 1996 dan 2008 dilihat dari standar jarak dan luas, ditunjukkan oleh koefisien $t$, masing-masing adalah 14,81 dan 2,72 pada taraf signifikansi 0,000.
\end{abstract}

Kata Kunci: Neraca Penggunaan Lahan, Penginderaan Jauh, SIG 
Penyusunan Neraca Perubahan Penggunaan Lahan Berdasarkan Pedoman Baku di Kecamatan Umbulharjo Kota

Yogyakarta dengan Menggunakan Teknik Penginderaan Jauh dan Sistem Informasi Geografis

\title{
STUDY ON LAND USE CHANGE IN UMBULHARJO YOGYAKARTA AIDED REMOTE SENSING TECHNIQUE AND GEOGRAPHIC INFORMATION SYSTEM
}

\begin{abstract}
This research aims to: (1) know the accuracy of the interpretation results of black and white panchromatic aerial photographs 1:8900 scale in 1996 and color Quickbird image 1:5400 scale in 2008 for the interpretation of land use, (2) arrange the balance sheet of the land use referring to the standard guidelines of land use distance, (3) make the balance sheet of the land use referring to the standard guidelines of land use width, and (4) know the difference of land use viewed from the standard distance and width of land use in the district of Umbulharjo Yogyakarta from 1996 to 2008. This research is a quantitative- descriptive research employing remote sensing techniques especially the interpretation of aerial photographs, QuickBird image, and Geographic Information Systems (GIS). The population in this research include the units of land use in the the district of Umbulharjo, Yogyakarta. The Sampling techniques to test accuracy employed in this research is proportional and purposive sampling technique. The numbers of research sample is determined based on the Formula Anderson. For the purpose of statistical analysis, the number of research sample is determined based on the nomogram Harry King with the degree of error of $6 \%$. The sampling techniques are proportional sampling and simple random sampling techniques. The data collection techniques used in this research consists of documentation, observation and image interpretation. The data analysis techniques in this study are testing the accuracy of the interpretation of the Confusion Matrix Calculation, GIS analysis (Overlay and Single Buffer) and t-test. The findings show that: (1) the interpretation of black and white panchromatic aerial photographs 1:8900 scale and Quickbird image in 1996 has the accuracy of 85\% and $90.02 \%$ respectively, (2) Based on interpretation of aerial photographs, the width of land use which is standardized based on the width standard is supposed to be 99.535 ha and there is 336.616 ha in the field. Based on the distance standard, the widest land use is the distance to the parks or 361.134 ha and the narrowest land use is the distance to the children's playground or 68.908 ha, (3) the balance sheet of land use indicated by the standardized land width in 2008 should be 117.153 ha but there is 282.116 ha in the field. Based on the standard distance to public facilities, land use is the widest land use is the distance to the city center, junior high schools, and parks. Each covers an area of 477.861 ha, and (4) there are significant differences between land use in 1996 and 2008 viewed from the standard of distance and width indicated by the $t$ coefficient of 14.81 and 2.72 respectively at the significance level of 0.000 .
\end{abstract}

Keywords : the balance sheet of land use, remote sensing, GIS

\section{PENDAHULUAN}

Kota-kota di Indonesia saat ini berkembang sangat pesat, selama kurun waktu 10 tahun terakhir muncul kurang lebih 31 kota baru dari hasil pemekaran beberapa kabupaten. Pada tahun 2008 merupakan tahun yang bersejarah karena jumlah penduduk kota melampaui jumlah penduduk perdesaan (Doni J. Widiantono dan Ishma Soepriadi, 2008:1-4).

Perkembangan penduduk kota yang pesat mengiringi berkembangnya kota-kota. Pertumbuhan penduduk kota berimplikasi pada semakin banyaknya kebutuhan lahan untuk permukiman dan sarana prasarana lainnya yang mengiringi permukiman. 
Keterbatasan lahan kota, rendahnya pengetahuan dan kesadaran lingkungan serta tingkat ekonomi masyarakat yang belum mapan mendorong terjadinya praktek-praktek pemanfaatan lahan yang tidak sesuai peruntukannya. Konflik-konflik sosial akibat pemanfaatan lahan di kota juga sering terjadi.

Di berbagai kota penyimpangan penggunaan lahan sangat banyak terjadi, termasuk juga di Kota Yogyakarta, penyimpangan tersebut berupa pemanfaatan jalur hijau di sepanjang bantaran Sungai Code menjadi permukiman, berdirinya perumahan baru di sepanjang bantaran Sungai Gajahwong, dan berbagai kasus penyimpangan penggunaan lahan lainnya di berbagai kota, yang akhir-akhir ini membawa dampak banjir dan membawa banyak korban harta dan jiwa. Fenomena perubahan penggunaan lahan merupakan aspek yang niscaya terjadi karena perkembangan kebutuhan dan kehidupan masyarakat, tetapi yang mengkhawatirkan adalah jika perubahan tersebut tak terkendali (unmanage).

Praktek yang dilakukan oleh masyarakat dalam menggunakan lahan di berbagai kota di Indonesia saat ini banyak yang tidak sesuai dengan pedoman baku. Bukti tidak mengacu pada pedoman baku adalah masyarakat tidak menyediakan lahan terbuka hijau privat, konversi lahan pertanian ke non pertanian secara besar-besaran tanpa kendali, pendirian bangunan di jalur hijau (green belt), minimnya ruang terbuka, taman bermain untuk anak-anak dan lain-lain.

Salah satu bagian dari Kota Yogyakarta yang sangat dinamis perkembangan penggunaan lahannya adalah Wilayah Kecamatan Umbulharjo, yakni wilayah kecamatan yang berada di bagian tenggara Kota Yogyakarta. Kecamatan ini juga merupakan kecamatan dengan wilayah yang paling luas di antara kecamatan lainnya di Kota Yogyakarta. Dinamika perubahan penggunaan lahan yang paling nyata adalah dari lahan pertanian ke permukiman, lahan terminal bis antar kota menjadi lahan kosong kemudian rencananya menjadi Pasar Seni, lahan pertanian menjadi lahan terminal baru (Giwangan). Perubahan ini jika dilihat dari standar luas dan jarak belum memperhatikan aspek keseimbangan, mengingat bahwa letaknya yang berada terlalu ke selatan sehingga jauh bila dijangkau dari wilayah kota yang lainnya. Penggunaan lahan di kecamatan ini juga lebih kompleks dan menarik dibandingkan dengan kecamatan lainnya. Di wilayah ini banyak terdapat penggunaan lahan yang berupa fasilitas umum milik pemerintah kota dan pemerintah provinsi. Penggunaan lahan untuk fasilitas umum milik pemerintah kota antara lain berupa Pasar Giwangan, stadion Mandalakrida, gedung perkantoran (balai kota, kantor DPRD, Bappeda, dan lain-lain), milik pemerintah provinsi antara lain: gedung kantor keuangan, taman makam pahlawan Kusumanegera, dan lain-lain.

Pemantauan kesesuaian penggunaan lahan belum sepenuhnya dilakukan oleh pemerintah secara komprehensif. Pemantauan hanya pada daerah-daerah yang mudah dijangkau, daerah yang mempunyai fasilitas-fasilitas penting dan pada pihak/pemilik bangunan yang mengajukan permohonan Ijin Mendirikan Bangunan (IMB). Dalam praktiknya masih banyak masyarakat yang mendirikan bangunan tanpa menimbang kesesuaian lahan. Sementara pemerintah sendiri, belum mempunyai instumen yang memadai untuk melakukan pemantauan (monitoring). Untuk memantau (monitoring) kesesuaian penggunaan lahan dengan pedoman baku diperlukan serangkaian data yang menggambarkan praktik penggunaan lahan masa lalu dan aktual oleh masyarakat. 
Penyusunan Neraca Perubahan Penggunaan Lahan Berdasarkan Pedoman Baku di Kecamatan Umbulharjo Kota Yogyakarta dengan Menggunakan Teknik Penginderaan Jauh dan Sistem Informasi Geografis

Rangkaian data tersebut dapat diperoleh secara cepat dan relatif lengkap melalui interpretasi citra penginderaan jauh.

Saat ini terdapat citra yang memiliki resolusi sangat tinggi (hyperresolution), diantaranya yang sangat populer adalah Quickbird. Citra ini pada mode pankromatik memiliki resolusi spasial 0,6 $\mathrm{m}$ dan 2,4 m pada mode multispektral. Citra ini mampu menyajikan informasi secara detail termasuk penggunaan lahan, bahkan sampai pada klasifikasi penggunaan lahan level IV. Meskipun memiliki resolusi yang tinggi tetapi untuk penerapannya di daerah penelitian belum diketahui secara pasti tingkat ketelitian hasil interpretasinya untuk keperluan pemantauan pemanfaatan penggunaan lahan dan perubahannya. Teknik penginderaan jauh juga memiliki kemampuan untuk merekam atau menampilkan objek yang sama dalam waktu yang berbeda secara berulang-ulang (multitemporal), dengan resolusi yang tinggi maka penginderaan jauh mampu menyajikan data yang detail, aktual dan dapat diketahui perkembangan perubahan penggunaan lahan dari waktu ke waktu.

Hasil interpretasi kedua citra tersebut selanjutnya dapat diolah dan dianalisis dengan menggunakan Sistem Informasi Geografis (SIG). Peta yang dihasilkan dengan memanfaatkan SIG berupa peta digital yang sangat bermanfaat dan leluasa dimodifikasi sesuai dengan perkembangan. Peta digital sangat penting, tidak semua kota memiliki peta digital penggunaan lahan berseri sehingga pemanfaatan lahan dapat dipantau kesesuaiannya berdasarkan pedoman baku.

Berdasarkan beberapa fakta di atas, dirumuskan masalah sebagai berikut: (1) Seberapa besar tingkat ketelitian hasil interpretasi foto udara pankromatik hitam putih skala 1:8900 tahun 1996 dan citra Quickbird pankromatik berwarna skala 1:5400 hasil perekaman tahun 2008 untuk interpretasi penggunaan lahan di wilayah Kecamatan Umbulharjo? (2) Bagaimnana neraca penggunaan lahan di daerah penelitian yang disusun berdasarkan data hasil interpretasi citra Quickbird dan foto udara yang mengacu kepada pedoman baku luas penggunaan lahan? (3) Bagaimana neraca penggunaan lahan di daerah penelitian yang disusun berdasarkan data hasil interpretasi citra Quickbird dan foto udara yang mengacu kepada pedoman baku jarak penggunaan lahan? (4) Apakah terdapat perbedaan penggunaan lahan dilihat dari standar luas dan standar jarak antara penggunaan lahan tahun 1996 dan 2008 di daerah penelitian berdasarkan hasil interpretasi citra Quickbird dan foto udara.

\section{METODE PENELITIAN}

Penelitian ini merupakan jenis penelitian deskriptif dengan menggunakan aplikasi teknik penginderaan jauh khususnya foto udara dan citra Quickbird liputan Kecamatn Umbulharjo dengan analisis manual dan SIG. Hasil interpretasi citra berupa peta penggunaan lahan. Masing-masing peta penggunaan lahan yang berbeda tahun tersebut dibandingkan dengan pedoman baku penggunaan lahan sehingga dapat diketahui tingkat kesesuaiannya dari standar (luas dan jarak). Pedoman baku penggunaan lahan (standar jarak dan luas) mengacu pendapat Chapin dalam Johara T.jayadinata (1999) dan permendiknas No 24 Tahun 2007 tentang standar luas fasilitas pendidikan (lihat tabel 1). Selanjutnya kedua peta ditumpangsusunkan dengan menggunakan SIG sehingga bisa diketahui perubahan penggunaan lahannya. 
Tabel 1. Standar Jarak Penggunaan Lahan dalam Kota

\begin{tabular}{|l|l|l|l|}
\hline No & Jenis Penggunaan Lahan (Prasarana) & $\begin{array}{c}\text { Jarak dari } \\
\text { tempat tinggal } \\
\mathbf{( k m )}\end{array}$ & $\begin{array}{c}\text { Jarak tempuh } \\
\text { dengan berjalan } \\
\text { kaki (menit) }\end{array}$ \\
\hline 1. & Pusat tempat kerja & $1,5-2,75$ & $20-30$ \\
\hline 2. & $\begin{array}{l}\text { Pusat kota (dengan pasar, dan } \\
\text { sebagainya) }\end{array}$ & $2,75-3,5$ & $30-45$ \\
\hline 3. & Pasar lokal & 0,75 & 10 \\
\hline 4. & Sekolah Dasar & 0,75 & 10 \\
\hline 5. & Sekolah Menengah Pertama & 1,5 & 20 \\
\hline 6. & Sekolah Lanjutan Atas & $1,5-2,75$ & $20-30$ \\
\hline 7 & Kampus & $1,5-2,75$ & $20-30$ \\
\hline 8 & Tempat bermain anak/ taman lokal & 0,75 & 10 \\
\hline 9 & Lahan Rekreasi/Olah raga & 1,5 & 20 \\
\hline 10. & Taman atau cagar & $2,75-5,5$ & $30-60$ \\
\hline 11. & Rumah sakit & $1,5-2,75$ & $20-30$ \\
\hline
\end{tabular}

Sumber: Chapin dalam Johara T. Jayadinata, (1999:160)

Standar luas sarana prasarana pendidikan yang lain termuat dalam Permendiknas No 24 Tahun 2007 tentang standar luas fasilitas pendidikan:

1. Taman kanak-kanak

Sesuai dengan perencanaan maka, dalam perencanaan TK ialah penduduk pendudkung minimal rata-rata 700 orang dengan luas lahan $1200 \mathrm{~m}^{2}$. Lokasi sebaiknya terletak di tengah-tengah kelompok keluarga, jumlah murid dengan standar 3 ruang kelas terdiri dari 35-45 murid disetiap ruang kelas.

2. Sekolah Dasar (SD)

Dibutuhkan sebuah SD dengan penduduk pendudkung minimal 5400 Orang dengan luas lahan $1500 \mathrm{~m}^{2}$, lahan berada di tengah-tengah kelompok keluarga dalam radius pencapaian dari daerah yang dilayani maksimum $1000 \mathrm{~m}$. Standar jumlah murid adalah 40 murid tiap kelas, untuk SD tipe A terdiri dari 12 kelas belajar, luas ruangan $100 \mathrm{~m}^{2}$ dengan luas lahan yang digunakan $3000 \mathrm{~m}^{2}$. Untuk SD tipe B terdiri dari 6 ruang kelas belajar, luas ruangan $633 \mathrm{~m}^{2}$, dengan jumlah lahan $2000 \mathrm{~m}^{2}$, sedaangkan SD tipe $C$ terdiri dari 3 ruang kelas, ruang kelas $251 \mathrm{~m}^{2}$ dengan luas lahan $1200 \mathrm{~m}^{2}$.

3. Sekolah Lanjutan Tingkat Pertama (SLTP)

Jumlah penduduk pendukung munimal 12.000 orang untuk sebuah SLTP, sedangkan luas lahannya $10000 \mathrm{~m}^{2}$. Lokasi digabung/ dikelompokan dengan taman dan lapangan olahraga. Standar murid SLTP tipe A terdiri dari 27 kelas, luas ruangan $3007 \mathrm{~m}^{2}$. Dengan luas lahan minimal $8000 \mathrm{~m}^{2}$. Untuk SLTP tipe B terdiri dari 18 kelas dengan luas ruang $2882 \mathrm{~m}^{2}$, dengan luas lahan minimal $9000 \mathrm{~m}^{2}$. Untuk SLTP tipe C terdiri dari 9 kelas dengan luas ruang $1502 \mathrm{~m}^{2}$, dan luas lahan minimal $6000 \mathrm{~m}$.

4. Sekolah Lanjutan Tingkat Atas (SLTA)

Jumlah penduduk pendudkung minimal 12.000 orang, untuk SLTA sedangkan luas lahan yang diperlukan $20.0000 \mathrm{~m}$. Kriteria lokasi digabungkan dengan taman dan lapangan olahraga. Standar 30 murid tiap ruang kelas dengan 14 kelas (pagi/sore) untuk sebuah SLTA. 
Penyusunan Neraca Perubahan Penggunaan Lahan Berdasarkan Pedoman Baku di Kecamatan Umbulharjo Kota Yogyakarta dengan Menggunakan Teknik Penginderaan Jauh dan Sistem Informasi Geografis

Di Indonesia standar luas penggunaan lahan kota untuk berbagai macam prasarana telah dibuat pedomannya oleh Ditjen Pembangunan Desa. Sebagai contoh lihat Tabel 2 di bawah ini:

Tabel 2. Standar Luas untuk Macam-macam Prasarana

\begin{tabular}{|c|l|c|}
\hline No & \multicolumn{1}{|c|}{ Prasarana } & $\begin{array}{c}\text { Standar luas lahan } \\
\text { (1.000 penduduk) }\end{array}$ \\
\hline 1 & Pusat Layanan Kesehatan & $200 \mathrm{~m}^{2}$ \\
\hline 2 & Masjid & $250 \mathrm{~m}^{2}$ \\
\hline 3 & Ruang terbuka & $5.000 \mathrm{~m}^{2}$ \\
\hline 4 & Tempat Olahraga & $3.000 \mathrm{~m}^{2}$ \\
\hline 5 & Tempat bermain anak-anak & $1.000 \mathrm{~m}^{2}$ \\
\hline 6 & Pasar & $500 \mathrm{~m}^{2}$ \\
\hline 7 & Pertokoan & $1.000 \mathrm{~m}^{2}$ \\
\hline 8 & Balai Pertemuan & $250 \mathrm{~m}^{2}$ \\
\hline
\end{tabular}

Sumber: Ditjen Pembangunan Desa dalam Johara T. Jayadinata (1999:162).

Variabel dari penelitian ini adalah tingkat ketelitian hasil interpretasi penggunaan lahan, jarak penggunaan lahan dan luas penggunaan lahan. Jumlah populasi untuk uji ketelitian berdasarkan hasil interpretasi foto udara dan citra Quickbird masing-masing sebanyak 461 polygon dan 650 polygon. Populasi untuk analisis statistik terdiri dari dua jenis, yakni (1) berdasarkan standar luas berdasarkan standard luas tahun 1996 adalah 235 unit dan pada tahun 2008 adalah 249 unit; dan (2) berdasarkan standar jarak, jumlah populasi tahun 1996 adalah 143 blok dan jumlah unit-unit penggunaan lahan permukiman hasil interpretasi citra Quickbird 250 blok.

Penentuan jumlah sampel untuk uji ketelitian hasil interpretasi menggunakan formula Anderson (Lo, 1996), yaitu:

$\mathrm{N}=\frac{4 \mathrm{QG}}{N^{2}}$, dengan ditetapkan tingkat ketelitian sebesar $85 \%$ dan tingkat kesalahannya $10 \%$ maka $\mathrm{N}=\frac{4,35.15}{10^{2}} \quad=51$ sampel.

Sampel untuk anlisis statistik ditentukan berdasarkan Nomogram Harry King dengan tingkat kesalahan $6 \%$, jumlah sampel untuk pengunaan lahan berdasarkan standard luas tahun 1996 adalah $38 \% \times 249 \times 1,195=113$ dan pada tahun 2008 adalah $39 \% \times 235 \times 1,195=110$. Jumlah sampel penggunaan lahan untuk permukiman berdasarkan standard jarak untuk tahun 1996 diperoleh sampel sebanyak 54\% x $143 \times$ $1,195=93$ blok. Jumlah sampel untuk blok permukiman tahun 2008 adalah $38 \%$ x $250 \times$ $1,195=114$ blok.

Teknik pengambilan sampel untuk uji ketelitian dilakukan dengan proporsional dan purposive sampling. Untuk analisis statistik, teknik pengambilan sampel dilakukan dengan proporsional dan simple random sampling. Teknik pengumpulan data dilakukan dengan dokumentasi, observasi, dan interpretasi citra.

Teknik analisis data yang dilakukan dalam penelitian ini adalah (1) confusion matrix calculation, digunakan untuk menguji ketelitian hasil interpretasi. (2) Analisis deskriptif, digunakan untuk mendeskripsikan kondisi data yang berupa mean, median, dan modus, tabel frekuensi, dan tabulasi silang; (3) Analisis SIG, khususnya dengan tumpangsusun (overlay) dan buffering; dan (4) analisis statistik dengan Uji-t. 


\section{HASIL PENELITIAN DAN PEMBAHASAN}

Berdasarkan uraian pada pembahasan di atas dapat ditarik sejumlah kesimpulan sebagai berikut:

\section{$\underline{\text { Hasil Uji Ketelitian Hasil Interpretasi }}$}

Berdasarkan uji ketelitian dengan menggunakan Confusion Matrix Calculation diketahui bahwa tingkat ketelitian hasil interpretasi foto udara pankromatik hitam putih skala 1:8900 tahun 1996 dan citra Quickbird berwarna skala 1:5400 tahun 2008 untuk interpretasi penggunaan lahan di wilayah Kecamatan Umbulharjo masing-masing adalah $85 \%$ dan $90,02 \%$.

Dibandingkan dengan foto udara tahun 1996, ketelitian hasil interpretasi pada citra Quickbird lebih tinggi. hal ini disebabkan karena: (1) citra Quickbird lebih baru tahun perekamannya, sehingga lebih mendekati fakta di lapangan; (2) skala pada citra Quickbird, meskipun telah diperkecil tidak mengurangi kemudahan interpretasi, karena tingkat kerincian tidak berkurang banyak, sehingga identifikasi objek lebih mudah dan jelas; (3) citra Quickbird kondisinya lebih baik dalam hal fisik maupun kenampakan penampilannya.

Uji ketelitian kategorik dilakukan untuk bertujuan untuk mengetahui tingkat ketelitian setiap kategori penggunaan lahan. Karena pada umumnya kesalahan interpretasi terjadi pada penggunaan lahan dalam satu kategori. Hasil uji ketelitian kategori masing-masing penggunaan lahan untuk foto udara dan Quicbird adalah sebagai berikut: permukiman (97,36 \% dan 97,5\%), lahan pertanian ( $80 \%$ dan 85\%), lahan transportasi dan industri (masing-masing 100\%), rekreasi dan olah raga (92,85\% dan 95,34\%), lahan jasa ( $81,57 \%$ dan $87,5 \%$ ), lahan perdagangan ( $84 \%$ dan $93,33 \%$ ), lahan tempat ibadah (masing-masing 100\%), dan lahan lain-lain (90,9\% dan 96,87\%). Hasil interpretasi foto udara menunjukkan bahwa dari semua kategori penggunaan lahan hanya 3 macam penggunaan lahan (pertanian, jasa, dan perdagangan) yang tidak memenuhi standar. Ketelitian kategori hasil interpretasi citra Quickbird menunjukan hasil yang lebih teliti karena semua kategori memiliki ketelitian di atas $85 \%$.

\section{Hasil Interpretasi Penggunaan Lahan}

Fenomena yang menarik adalah perubahan penggunaan lahan dari pertanian menjadi permukiman dan lainnya yang menyertai permukiman. Berdasarkan peta perubahan penggunaan lahan (gambar 3) diketahui lahan permukiman menempati area seluas 361,134 hektar pada tahun 1996, menjadi 477,861 hektar pada 2008. Ini berarti ada perluasan lahan permukiman sebanyak 116,727 hektar (32,32\%). Penggunaan lahan yang mengalami perluasan kedua adalah lahan untuk jasa, yakni dari 80,514 hektar pada tahun 1996 menjadi 91,760 hektar, mengalami penambahan luas 11,246 hektar (13,97\%). Perubahan penggunaan lahan yang besifat menyempit meliputi, pertanian (sawah dan KC), lahan lain-lain (lahan kosong dan lahan sedang dibangun). Lahan yang tidak mengalami perubahan adalah lahan untuk olahraga dan rekreasi yakni Stadion Mandala Krida, Kebun binatang Gembira Loka, dan GOR Amongrogo. Rincian masing-masing penggunaan lahan dapat dilihat pada gambar 1,2, dan 3 serta tabel 2. 
Penyusunan Neraca Perubahan Penggunaan Lahan Berdasarkan Pedoman Baku di Kecamatan Umbulharjo Kota

Yogyakarta dengan Menggunakan Teknik Penginderaan Jauh dan Sistem Informasi Geografis

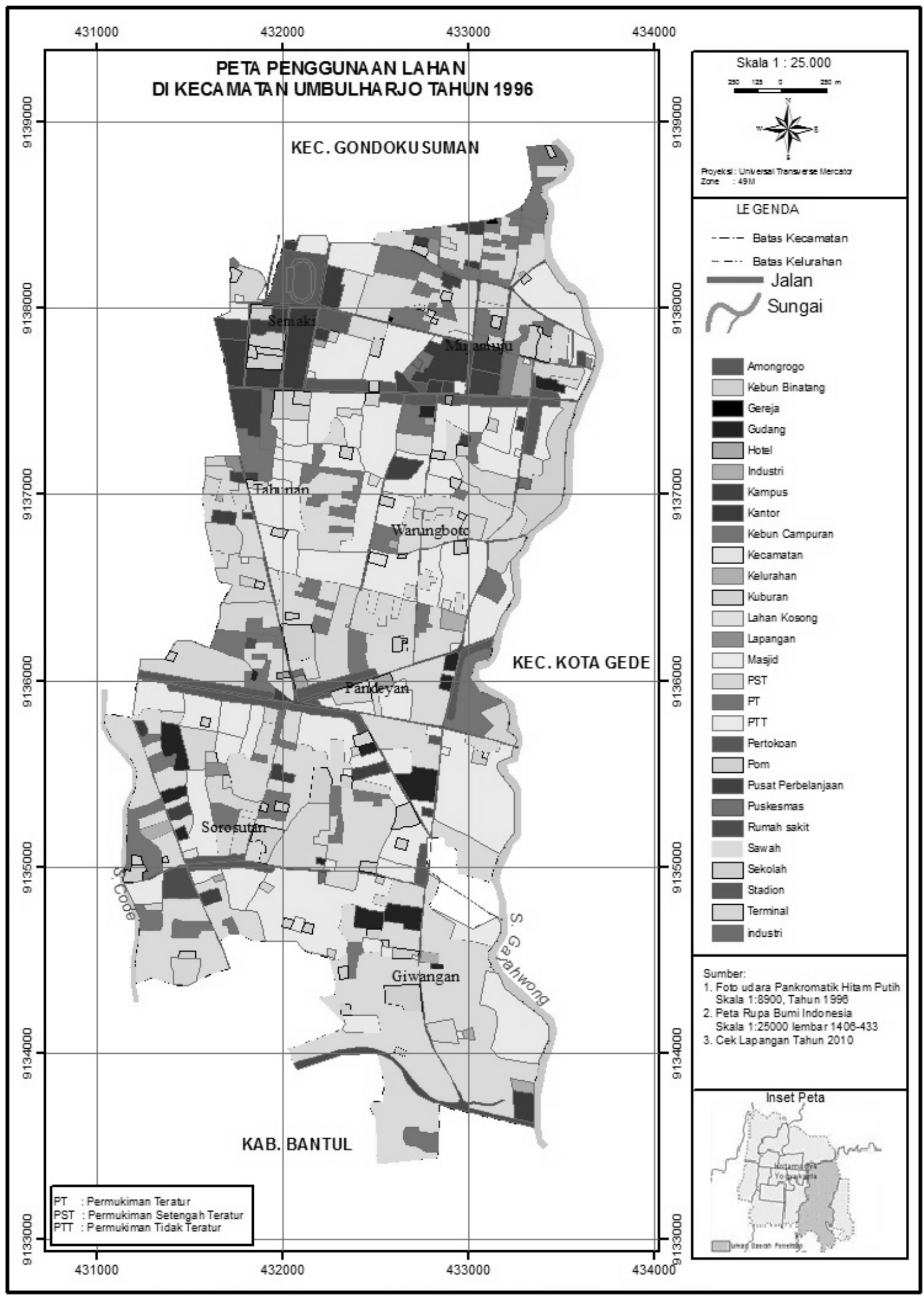

Gambar 1. Peta Penggunaan Lahan di Kecamatan Umbulharjo Tahun 1996 


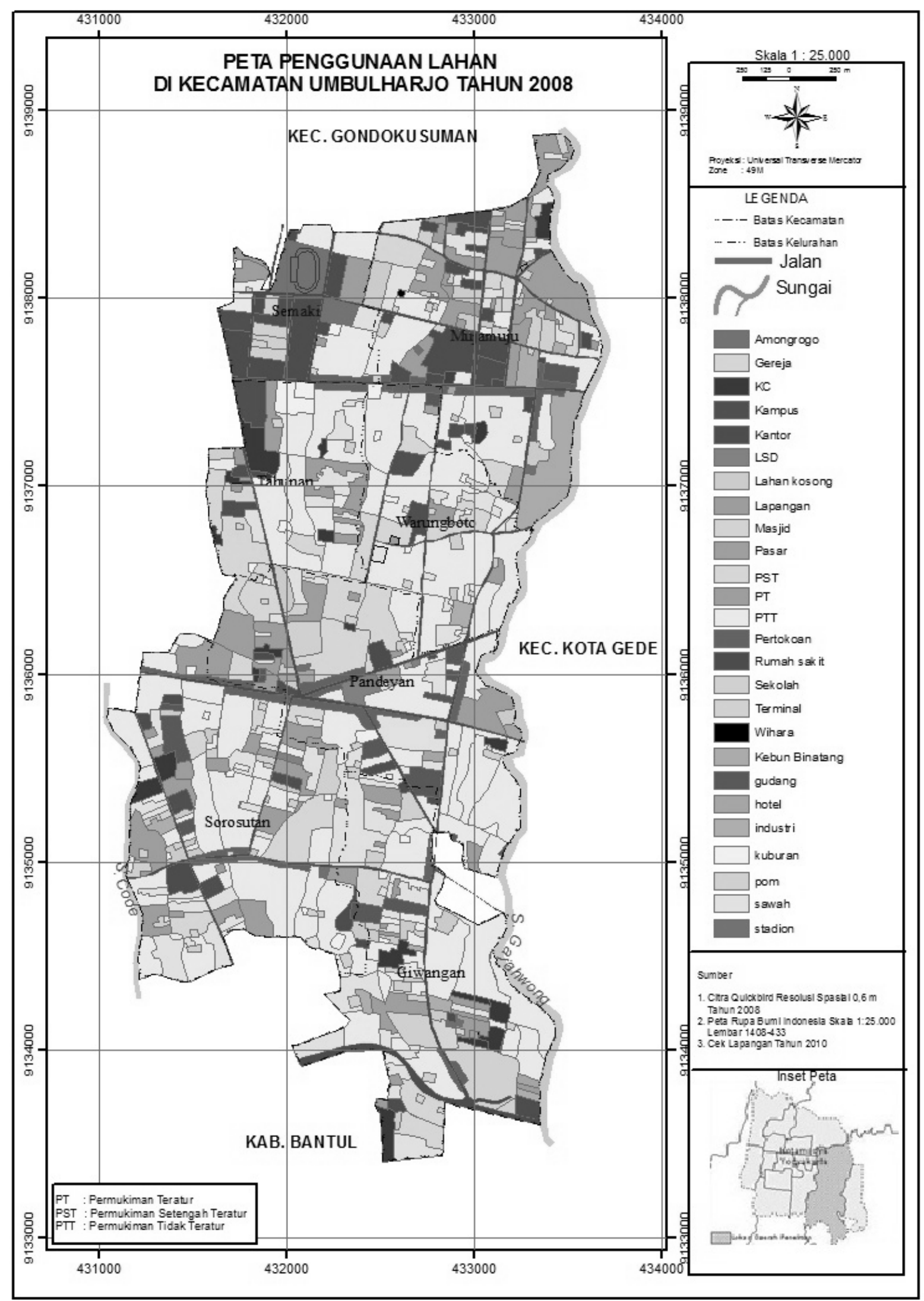

Gambar 2. Peta Penggunaan Lahan di Umbulharjo Tahun 2008 
Penyusunan Neraca Perubahan Penggunaan Lahan Berdasarkan Pedoman Baku di Kecamatan Umbulharjo Kota

Yogyakarta dengan Menggunakan Teknik Penginderaan Jauh dan Sistem Informasi Geografis

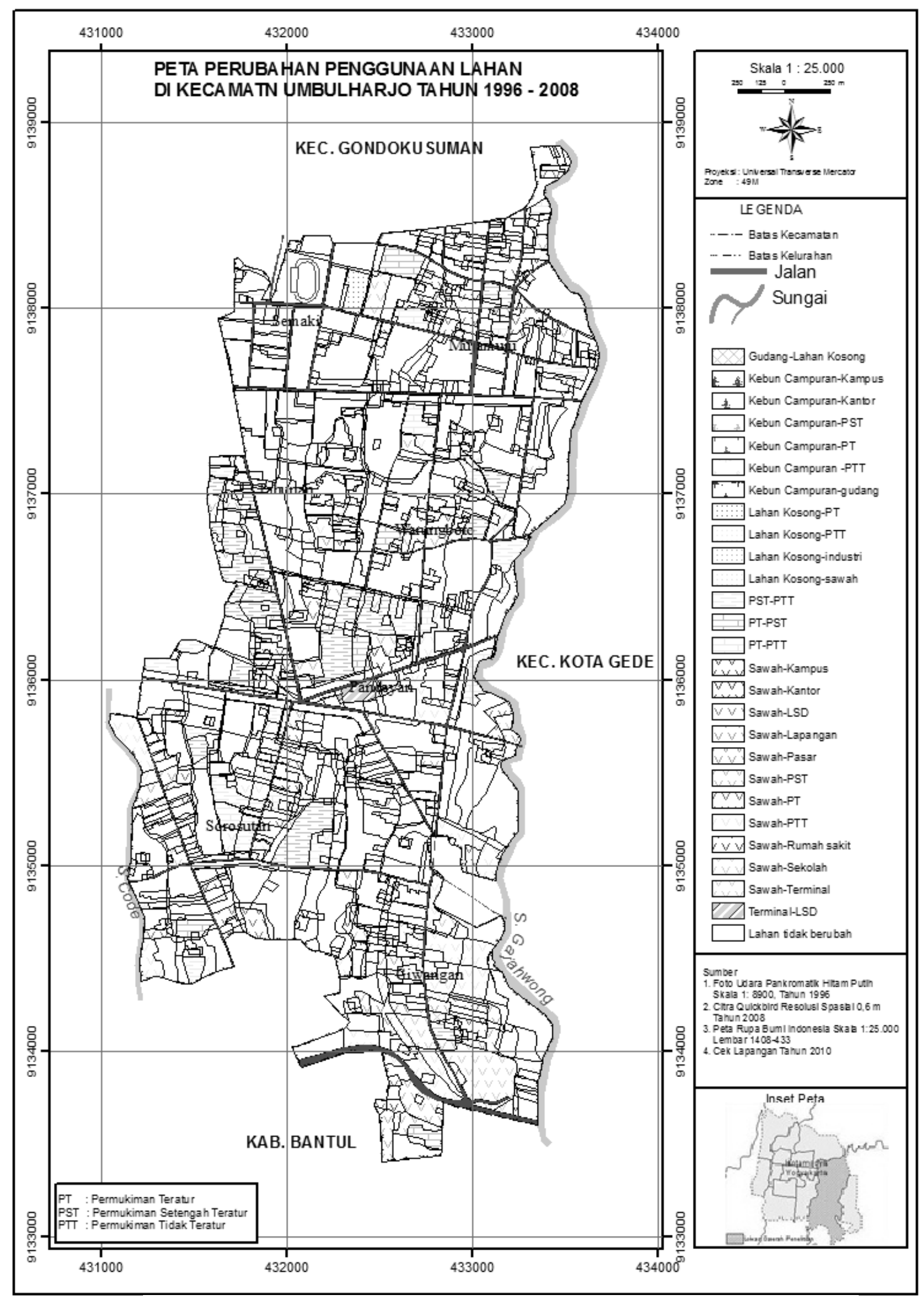

Gambar 3. Peta Perubahan Penggunaan Lahan 1996 - 2008 
Tabel 2. Bentuk dan Luas penggunaan Lahan di Kecamatan Umbulharjo Tahun 1996 dan 2008

\begin{tabular}{|c|c|c|c|c|}
\hline \multirow[t]{2}{*}{ No } & \multirow{2}{*}{ Bentuk Penggunaan Lahan } & \multicolumn{2}{|c|}{ Luas (ha) } & \multirow{2}{*}{$\begin{array}{l}\text { Perubahan } \\
\text { (ha) }\end{array}$} \\
\hline & & 1996 & 2008 & \\
\hline \multirow[t]{4}{*}{1.} & Permukiman & - & - & - \\
\hline & Teratur & 71,263 & 96,901 & $+25,638$ \\
\hline & Setengah Teratur & 70,856 & 85,773 & $+14,917$ \\
\hline & Tidak Teratur & 219,015 & 295,187 & $+76,172$ \\
\hline \multirow[t]{5}{*}{2.} & Perdagangan & - & - & - \\
\hline & Pasar & - & 5,472 & $+5,472$ \\
\hline & Pom bensin & 0,778 & 1,415 & $+0,637$ \\
\hline & Pertokoan & 16,176 & 23,616 & $+7,440$ \\
\hline & Pusat perbelanjaan & 0,433 & 0,589 & $+0,156$ \\
\hline \multirow[t]{3}{*}{3.} & Industri & - & - & - \\
\hline & Pabrik/perusahaan & 14,801 & 16,769 & $+1,968$ \\
\hline & Gudang & 5,67 & 7,972 & $+2,302$ \\
\hline \multirow[t]{3}{*}{4.} & Transportasi & - & - & - \\
\hline & Jalan & 37,56 & 40,364 & $+2,804$ \\
\hline & Stasiun/terminal & 1,746 & 5,915 & $+4,169$ \\
\hline \multirow[t]{6}{*}{5.} & Jasa Kelembagaan & - & - & - \\
\hline & Perkantoran & 27,456 & 33,217 & $+5,761$ \\
\hline & Kampus & 19,437 & 23,453 & $+4,016$ \\
\hline & Sekolah & 29,259 & 29,976 & $+0,717$ \\
\hline & Rumah sakit & 3,082 & 4,332 & $+1,249$ \\
\hline & Non kelembagaan(Perhotelan) & 1,530 & 3,288 & $+1,758$ \\
\hline \multirow[t]{5}{*}{6.} & Rekreasi & - & - & - \\
\hline & Kebun binatang & 8,149 & 8,149 & - \\
\hline & Lapangan Olah raga & 1,599 & 2,102 & $+0,503$ \\
\hline & Stadion & 6,787 & 6,787 & - \\
\hline & Gedung Olah raga & 1,851 & 1,851 & - \\
\hline \multirow[t]{4}{*}{7.} & Tempat Ibadah & - & - & - \\
\hline & Masjid & 2,070 & 3,372 & $+1,302$ \\
\hline & Gereja & 0,169 & 0,509 & $+0,340$ \\
\hline & Wihara & - & 0,07 & $+0,07$ \\
\hline \multirow[t]{3}{*}{8.} & Pertanian & - & - & - \\
\hline & Sawah & 228,963 & 85,113 & $-143,850$ \\
\hline & $\mathrm{KC}$ & 18,218 & 9,580 & $-8,638$ \\
\hline \multirow[t]{4}{*}{9.} & Lain-lain & - & - & - \\
\hline & Kuburan & 9,653 & 10,425 & $-0,772$ \\
\hline & Lahan Kosong & 15,441 & 7,232 & $-8,209$ \\
\hline & Lahan Sedang dibangun & - & 2,580 & - \\
\hline & Jumlah & 812,00 & 812,00 & 812,00 \\
\hline
\end{tabular}

Sumber: Hasil Interpretasi Foto udara tahun 1996, citra Quicbird tahun 2008 dan cek lapangan

Neraca penggunaan lahan yang disusun berdasarkan data hasil interpretasi foto udara dan citra Quickbird yang mengacu kepada pedoman baku luas penggunaan lahan, yakni: 
Penyusunan Neraca Perubahan Penggunaan Lahan Berdasarkan Pedoman Baku di Kecamatan Umbulharjo Kota

Yogyakarta dengan Menggunakan Teknik Penginderaan Jauh dan Sistem Informasi Geografis

1. Neraca luas penggunaan lahan menurut hasil interpretasi foto udara

a. Standard Luas SD

Dari 7 kelurahan yang ada, hanya Kelurahan Tahunan yang memiliki SD yang luasnya tidak meemenuhi standar, baik pada tahun 1996 maupun 2008. Seharusnya dengan jumlah penduduk usia SD sebanyak 1126 tersedia SD dengan luas 0,704 hektar tetapi hanya tersedia 0,459 hektar.

b. Standar Luas SMP

Penduduk usia SMP di Kecamatan Umbulharjo yang berjumlah 2.872 jiwa memerlukan lahan sesuai pedoman baku seluas 3,144 hektar. Sementara fakta di lapangan berdasarkan hasil interpretasi citra Quickbird hanya terdapat SMP dengan luas 3,978 hektar. Dengan kata lain secara keseluruhan luas SMP di Kecamatan Umbulharjo tidak memenuhi standard, dengan asumsi bahwa semua SMP hanya 1 lantai. Jika dilihat per kelurahan terdapat 4 kelurahan yang memiliki luas SMP yang sesuai yakni Giwangan, Sorosutan, Mujamuju, dan Semaki. Pada tahun 2008 tidak terjadi perubahan yang berarti.

c. Standar Luas SMA/SMK

Dilihat dari jumlah standard penduduk pendukung luas SMA di daerah penelitian telah mencukupi karena dengan jumlah penduduk sebanyak 58.475 jiwa, hanya diperlukan luas SMA seluas 9,746 hektar. Hanya saja bila dilihat kesesuaiannya di tiap kelurahan, banyak kelurahan yang luas SMA-nya tidak sesuai standar, hanya Sorosutan dan Semaki yang sesuai standar.

d. Standar Luas untuk Prasarana Pusat Layanan Kesehatan

Dilihat dari sebaran per kelurahan, hanya 3 kelurahan yang memiliki luas prasarana pelayanan kesehatan yang sesuai, yakni Sorosutan, Pandeyan, dan Mujamuju. Secara keseluruhan untuk melayani penduduk Kecamatan Umbulharjo yang berjumlah 58.475 jiwa, diperlukan lahan pelayanan kesehatan seluas 1,169 hektar, dan tersedia lahan seluas 4,362 hektar. Dengan demikian secara umum luas pusat pelayan kesehatan seluruh wilayah Kecamatan Umbulharjo telah memenuhi standard. Pada tahun 2008, Luas prasarana kesehatan di wilayah Kecamatan Umbulharjo dengan jumlah penduduk 75.835 jiwa, menurut standard diperlukan lahan untuk pelayanan kesehatan seluas 1,515 hektar kenyataannya terdapat lahan untuk kesehatan seluas 6,839 hektar, sehingga semuanya memnuhi standar.

e. Standard Luas untuk Prasarana Masjid

Baik pada tahun 1996 maupun 2008, semua bagian wilayah penelitian telah mempunyai luas tempat ibadah/masjid yang memenuhi standar.

f. Standar Luas untuk ruang terbuka hijau

Semuanya telah memenuhi standar, karena luas standar yang diperlukan adalah 29,233 hektar, faktanya di lapangan tersedia 265,983 hektar, atau $+236,75$ hektar. Pada tahun 2008, di Kelurahan Semaki terjadi penyempitan ruang terbuka hijau, sehingg luasnya menjadi tidak memenuhi standar. 
g. Standar Luas untuk Prasarana Tempat Olah raga

Secara keseluruhan luas prasarana olah raga di Kecamatan Umbulharjo dilihat dari standard luas tidak memenuhi, mengingat bahwa dengan jumlah penduduk 58. 475 jiwa diperlukan lapangan olahraga dengan luas 17,540 hektar, tetapi fakta di lapangan hanya tersedia lapangan olah raga dengan luas 10,326 hektar. Dari tujuh kelurahan hanya ada tiga kelurahan yang memiliki lapangan olah raga yakni Kelurahan Sorosutan, Mujamuju dan Semaki. Menurut data tahun 2008, hanya Kelurahan Semaki yang memiliki prasarana olah raga dan rekreasi yang sesuai standar.

h. Standard Luas untuk Prasarana Tempat Bermain

Secara keseluruhan wilayah penelitian telah memenuhi standar dalm hal tersedianya luas tempat bermain. Diperlukan 5,847 hektar, sementara luas tempat bermain yang tersedia di lapangan adalah 8,149 hektar. Dilihat sebarannya per kelurahan pada tahun 1996 dan 2008, maka hanya Kelurahan Mujamuju yang sesuai standar.

i. Standard Luas untuk Prasarana Pertokoan

Luas masing-masing kompleks pertokoan di setiap kelurahan telah memenuhi standard yang diperlukan. Lahan pertokoan yang paling luas terdapat di Kelurahan Semaki, yakni 4,680 hektar.

Dari 10 macam kelas penggunaan lahan di wilayah Kecamatan Umbulharjo hanya tiga macam yang tidak memenuhi standar, yakni penggunaan lahan untuk SMA, tempat olah raga, dan pasar. Luas penggunaan lahan yang distandarisasi berdasarkan standar baku adalah 99,535 hektar, dan memenuhi standar adalah 336,616 hektar.

Bila dilihat sebarannya per kelurahan, maka semua Kelurahan memiliki penggunaan lahan yang luasnya tidak memenuhi standar luas. Kelurahan yang paling banyak memiliki lahan yang memenuhi standar luas adalah Kelurahan Mujamuju dan yang paling sedikit memenuhi standar luas adalah Kelurahan Tahunan.

2. Neraca luas penggunaan lahan menurut hasil interpretasi citra Quickbird

Berdasarkan hasil interpretasi citra quickbird diperoleh susunan neraca sebagai berikut: pada tahun 2008 kondisi penggunaan lahan lebih baik karena hanya ada satu kelas penggunaan lahan yang tidak sesuai standar, yakni penggunaan lahan untuk SMA. Di daerah penelitian penggunaan lahan yang distandarisasi seharusnya memiliki luas 117,153 hektar, kenyataannya di lapangan terdapat penggunaan lahan yang memenuhi standar adalah 282,116 hektar.

Neraca penggunaan lahan per kelurahan ditunjukkan oleh jumlah kelas penggunaan lahan yang sesuai dengan standar. Dari 7 kelurahan yang ada, Kelurahan Giwangan dan Mujamuju merupakan kelurahan yang paling banyak memiliki kelas penggunaan lahan yang sesuai, yang tidak sesuai hanya penggunaan lahan untuk tempat bermain. Kelurahan yang paling banyak memiliki luas penggunaan lahan yang sedikit memenuhi standar luas adalah Kelurahan Tahunan. 
Penyusunan Neraca Perubahan Penggunaan Lahan Berdasarkan Pedoman Baku di Kecamatan Umbulharjo Kota Yogyakarta dengan Menggunakan Teknik Penginderaan Jauh dan Sistem Informasi Geografis

Neraca penggunaan lahan di daerah penelitian yang disusun berdasarkan data hasil interpretasi citra Quickbird dan foto udara yang mengacu kepada pedoman baku jarak penggunaan lahan.

1. Neraca jarak penggunaan lahan menurut hasil interpretasi foto udara

Neraca penggunaan lahan berdasarkan standar jarak berupa perbandingan luas penggunaan lahan untuk permukiman yang memenuhi standar jarak terhadap fasilitas umum dengan luas standar menurut pedoman baku. Luas pengunaan lahan untuk permukiman di wilayah Kecamatan Umbulharjo yang memenuhi standar jarak berbeda-beda. Penggunaan lahan untuk permukiman yang paling luas memenuhi standar jarak terhadap pusat kota dan taman/cagar alam, yakni masing-masing 361,134 hektar, diikuti oleh jarak terhadap SD (347,427 hektar), dan luas permukiman yang paling sempit adalah yang memiliki jarak terhadap tempat bermain anak/taman lokal.

Neraca penggunaan lahan berdasarkan jarak terhadap fasilitas umum per kelurahan, ditunjukkan oleh perbedaan jumlah luas penggunaan lahan yang sesuai dan tidak sesuai terhadap jarak standar. Dari ketujuh kelurahan yang ada, Kelurahan Mujamuju dan Semaki merupakan kelurahan yang paling banyak memiliki kelas lahan permukiman yang sesuai standar.

2. Neraca jarak penggunaan lahan menurut hasil interpretasi citra Quickbird

Penggunaan lahan untuk permukiman di daerah penelitian yang memenuhi standar jarak terhadap fasilitas umum pada tahun 2008 menunjukkan perubahan yang berarti karena kesesuaian penggunaan lahan untuk permukiman semakin banyak yang memenuhi standar jarak, bahkan terhadap semua jenis fasilitas umum (kecuali terhadap tempat bermain anak). Pada tahun 1996 luas permukiman yang tidak memenuhi standar jarak terhadap tempat bermain anak adalah 292,226 hektar menjadi 303,401 hektar. Pada kurun waktu 1996-2008 terjadi pertumbuhan permukiman baru sementara fasilitas tempat bermain anak tidak bertambah.

Berdasarkan hasil analisis dengan uji t diketahui bahwa :

1. Terdapat perbedaan yang signifikan antara penggunaan lahan tahun 1996 dan tahun 2008 dilihat dari standar luas di daerah penelitian berdasarkan hasil interpretasi foto udara. Hal ini ditunjukkan oleh koefisien $\mathrm{t}=-14,81$ dengan signifikansi 0,000 pada taraf signifikan 0,05 .

2. Terdapat perbedaan yang signifikan antara penggunaan lahan tahun 1996 dan tahun 2008 dilihat dari standar jarak di daerah penelitian berdasarkan hasil interpretasi citra Quickbird. Hal ini ditunjukkan oleh koefisien $t=2,720$ dengan signifikansi 0,000 pada taraf signifikan 0,05.

\section{Kesimpulan}

Berdasarkan uraian di atas dapat ditarik kesimpulan sebagai berikut:

1. Berdasarkan uji ketelitian dengan menggunakan Confusion Matrix Calculation diketahui bahwa tingkat ketelitian hasil interpretasi foto udara pankromatik hitam 
putih skala 1:8900 tahun 1996 dan citra Quickbird berwarna skala 1:5400 tahun 2008 untuk interpretasi penggunaan lahan di wilayah Kecamatan Umbulharjo masingmasing adalah $85 \%$ dan 90,02\%. Uji ketelitian kategorik hasil interpretasi foto udara menunjukkan bahwa dari semua kategori penggunaan lahan hanya 3 macam penggunaan lahan (pertanian, jasa, dan perdagangan) yang tidak memenuhi standar. Ketelitian kategori hasil interpretasi citra Quickbird menunjukan hasil yang lebih teliti karena semua kategori memiliki ketelitian di atas $85 \%$.

2. Neraca penggunaan lahan berdasarkan data hasil interpretasi foto udara dan citra Quickbird yang mengacu pedoman baku luas penggunaan lahan, yakni:

a. Neraca luas penggunaan lahan menurut hasil interpretasi foto udara

Di daerah penelitian hanya 3 macam yang tidak memenuhi standar, yakni penggunaan lahan untuk SMA, tempat olah raga, dan pasar. Luas penggunaan lahan yang distandarisasi berdasarkan standar baku adalah 99,535 hektar, dan memenuhi standar adalah 336,616 hektar. Dilihat sebarannya per kelurahan, semua Kelurahan memiliki penggunaan lahan yang luasnya tidak memenuhi standar luas.

b. Neraca luas penggunaan lahan menurut hasil interpretasi citra Quickbird

Pada tahun 2008 kondisi penggunaan lahan lebih baik karena hanya ada satu kelas penggunaan lahan yang tidak sesuai standar, yakni penggunaan lahan untuk SMA. Penggunaan lahan yang distandarisasi luasnya 117,153 hektar, penggunaan lahan yang memenuhi standar adalah 282,116 hektar.

3. Neraca penggunaan lahan berdasarkan data hasil interpretasi citra Quickbird dan foto udara berdasar pedoman baku jarak penggunaan lahan.

a. Neraca jarak penggunaan lahan menurut hasil interpretasi foto udara

Neraca ini berupa perbandingan luas penggunaan lahan untuk permukiman yang memenuhi standar jarak terhadap fasilitas umum dengan luas standar menurut pedoman baku. Penggunaan lahan untuk permukiman yang paling luas memenuhi standar jarak terhadap pusat kota dan taman/cagar alam, yakni masing-masing 361,134 hektar, diikuti oleh jarak terhadap SD (347,427 hektar), dan luas permukiman yang paling sempit adalah yang memiliki jarak terhadap tempat bermain anak/taman lokal. Neraca penggunaan lahan berdasarkan jarak terhadap fasilitas umum per kelurahan, menunjukkan bahwa ketujuh kelurahan yang ada, Kelurahan Mujamuju dan Semaki merupakan kelurahan yang paling banyak memiliki kelas lahan permukiman yang sesuai standar.

b. Neraca jarak penggunaan lahan menurut hasil interpretasi citra Quickbird

Pada tahun 1996 luas permukiman yang tidak memenuhi standar jarak terhadap tempat bermain anak adalah 292,226 hektar menjadi 303,401 hektar. Pada kurun waktu 1996-2008 terjadi pertumbuhan permukiman baru sementara fasilitas tempat bermain anak tidak bertambah. 
Penyusunan Neraca Perubahan Penggunaan Lahan Berdasarkan Pedoman Baku di Kecamatan Umbulharjo Kota

Yogyakarta dengan Menggunakan Teknik Penginderaan Jauh dan Sistem Informasi Geografis

4. Berdasarkan hasil analisis dengan uji t diketahui bahwa :

a. Terdapat perbedaan yang signifikan antara penggunaan lahan tahun 1996 dan tahun 2008 dilihat dari standar luas di daerah penelitian berdasarkan hasil interpretasi foto udara.

b. Terdapat perbedaan yang signifikan antara penggunaan lahan tahun 1996 dan tahun 2008 dilihat dari standar jarak di daerah penelitian berdasarkan hasil interpretasi citra Quickbird.

\section{DAFTAR PUSTAKA}

Doni J. Widiantono dan Ishma Soepriadi, 2008. Menakar Kinerja Kota Kota Di Indonesia. Bulletin Penata Ruang Nomor 1-4.

Johara T. Jayadinata, 1999. Tata Guna Lahan Dalam Perencanaan Pedesaan Perkotaan dan Wilayah. Bandung: ITB.

Lo, CP, 1996. Penginderaan Jauh Terapan. Terjemahan Bambang Purbowaseso. Judul Asli: Applied Remote Sensing. Jakarta: UI Press.

Permendiknas No 24 Tahun 2007 tentang standar luas fasilitas pendidikan. 